\title{
Serum Biochemical Parameters of Four Fresh Water Indian Carps from a Local Aquatic Body
}

\author{
Raghavendra Kulkarni \& Pruthviraj Bedjargi \\ Department of studies in zoology, \\ Gulbarga University, Kalaburgi \\ rskgug@gmail.com
}

\begin{abstract}
The serum biochemical parameters such as protein, glucose, cholesterol, triglycerides have been studied in four fresh water Indian carps collected from a local aquatic body to assess the normal levels of these blood parameters in comparison to the other fresh water fishes reported, so as to find out their health condition and survival in a particular aquatic body. It is reported that the assessment of health condition can be determined based on the blood biochemical parameters and it is well known that certain blood parameters serve as reliable indicators of fish health. The results of the above serum parameters in all the four carp fishes carried out in the present study found to be under normal ranges for protein (2.90-3.59g/dl), glucose (18.00 $29.01 \mathrm{mg} / \mathrm{dl})$, cholesterol (202.16-272mg/dl), triglyceride $(259.00-336.83 \mathrm{mg} / \mathrm{dl})$ compared to as reported in other fresh water fishes and can be suggested that the fishes inhabiting in the aquatic body are healthy and the environmental conditions are favourable for their survival.
\end{abstract}

Keywords: Blood biochemicals, Indian Fresh water carp fishes.

\section{INTRODUCTION}

One of the difficulties in assessing the state of health of natural fish population has been the paucity of reliable references of the normal condition. In pursuant to this goal, many fish physiologists have turned to studies of haematology, probably because it has proved a valuable diagnostic tool in evaluating health condition. Although fish haematology continues to offer the potential of a valuable tool, progress in establishing normal range values for blood parameters has been slow and literature in this area is isolated and often incomplete (Mawdesley - Thomas, 1971). Only a few normal values for a small number of hematological parameters have been established for some teleosts, but these values range widely due to the lack of standardized collecting and measuring techniques (Blaxhall, 1972). Haematological studies on fishes have assumed greater significance due to the increasing emphasis on pisciculture and greater awareness of the pollution of natural freshwater resources in the tropics. Such studies have generally been used as an effective and sensitive index to monitor physiological and pathological changes in fishes (Chekrabarty and Banerjee, 1988).It is well known that certain blood parameters serve as reliable indicators of fish health (Bond, 1979). Therefore, the changes associated with haematological parameters established, which could be used in diseases diagnosis and in guiding the implementation of treatment or preventive measures. These measures are essential in fish farming and fish industry also (Roberts, 1981). Owing to the paucity of information on the haematology of Indian fresh water fishes especially on the locally available fresh water fishes, the present study is undertaken to find out the normal values of some serum biochemical constituents and its variation with respect to different types of fish species under a specific environmental conditions. Among the species available in Gulbarga carps are prominent fish found in freshwater habitats and are considered as commercially important fishes and are being consumed by large population. The present study besides providing information on some haematological characteristics of local fishes, it may help us increasing our fundamental knowledge of comparative blood physiology and to establish a "normal", haematological profile of the Indian fresh water carp fishes from a particular aquatic body which is lacking and provide a basis for future comparative surveys.

\section{MATERIAL AND MeTHODS}

The Indian carp fishes such as Labeo rohita, catla catla, cirrhana mrigala and Labeo fimbriatus (Fig 1) are collected from Khaja kotnoor aquatic body by using caste net with the help of local fisherman. 
The fish were then placed belly upwards and blood samples obtained from the caudal circulation with the aid of $2 \mathrm{~cm}$ disposable plastic syringe and a 21 gauge disposable hypodermic needle. Blood was taken under gentle aspiration until about $2 \mathrm{ml}$ has been obtained and blood serum was obtained by centrifugation and then used for the determination of biochemical parameters. All determinations were carried out in duplicates for each sample.

\section{Blood biochemical Parameters}

Total Serum Proteins (TP): The total serum proteins were measured by using the modified Biuret method, end point assay as described by Lawrence, (1986), using commercial kit available in the market, which is based on the reaction. The peptide bond of proteins reacts with cupric ions in alkaline solution to form a coloured chelate, the absorbance which measured at $578 \mathrm{~nm}$. The biuret reagent contains sodium potassium tartrate, which helps in maintaining stability of this complex at alkaline $\mathrm{pH}$. The absorbance of colour is proportional to the concentration of total protein in the sample.

Determination of Serum Glucose: Glucose is determined by (GOD-POD) Glucose oxidase peroxidase, end point and assay method. (Using commercial kit available in the market), the substrate $\beta$-D-Glucose oxidase to form gluconic acid and hydrogen peroxide. The hydrogen peroxide so generated oxidises the chromogen system consisting of 4-amino antipyrine and phenolic compound to a red quinoeimine dye. The intensity of the colour produced is proportional to the glucose concentration and is measured at $505 \mathrm{~nm}$ in the spectrophotometer.

Total Cholesterol: is determined by (CHOD-PAP) cholesterol oxidase - phenol amino phenazone method, (using commercial kit available in the market), cholesterol esters are hydrolysed by cholesterol esterase (CE) to give free cholesterol and fatty acids .in subsequent reaction, cholesterol oxidase oxidises the 3-OH group of free cholesterol to liberate cholest -4-en-3-one and hydrogen peroxide. In presence of peroxidase (POD) hydrogen peroxide couples with 4-aminoantipirin (4-AAP) and phenol to produce red dye. Absorbance of coloured dye is measured at $505 \mathrm{~nm}$ and is proportional to amount of total cholesterol concentration in the sample.

Total Triglycerides: (TG) is determined by (GPO-PAP) glycerol-3-phosphate oxidase - phenol aminophenazone end point assay method. (using commercial kit available in the market), triglycerides are hydrolysed by lipoprotein lipase to produce glycerol and free fatty acids, in presence of glycerol kinase, adenosine triphosphate phosphorylates glycerol to produce glycerol 3-phosphate is further oxidized by glycerol 3-phosphate to produce dihydroxyacetone phosphate and $\mathrm{H}_{2} \mathrm{O}_{2}$. In presence of peroxidase, hydrogen peroxide couples with 4-amino antipyrine and 4-chlorophynol to produce red dye. Absorbance of coloured dye is measured at $505 \mathrm{~nm}$ and is proportional to triglycerides concentration in the sample.

Statistical Treatment of the Data: The experimental data was analyzed statistically by adopting varied statistical methods. Standard deviation and the student's- $t$ ' test was carried out to know the levels of significance using the standard formula. All the values of $\mathrm{P}$ below 5\% level are designated as significant, and the values above 5\% level are designated as non-significant (Mungikar, 2003).

\section{ObServations}

The normal blood biochemical studies such as protein, glucose, cholesterol, HDL, LDL and triglycerides (TG) are presented with range of these parameters (Table - 1).

Total Protein: Proteins are high molecular weight polymers of group of low molecular weight monomers called amino acids. These nitrogenous compounds are most abundant substances in cell protoplasm. Proteins also serve as major components of blood epithelial tissues and connective tissues in animals and they serve as a source of energy and fat. Protein in the fishes is ranged from 2.90 $3.59 \mathrm{~g} / \mathrm{dl}$, with an overall mean of $3.15 \mathrm{~g} / \mathrm{dl}$. The values are presented in the Table -1 .

Blood Glucose: Once in the blood stream, absorbed nutrients are distributed to the cells of the body, where they undergo many remarkable changes. The sum of total of these changes has been named metabolism. It includes energy requiring synthesis of new complex organic compounds (anabolism) and energy releasing degradation of absorbed nutrients to simple end products such as carbon dioxide and water (catabolism). The major function of carbohydrate in metabolism is as a fuel to be oxidized and provide energy for other metabolic process. Both fructose and galactose are converted into 
glucose by the liver and carbohydrate is utilized by the cells in the form of glucose. Once in blood, glucose travels throughout the body. It comes in contact with the cells. In the fishes blood glucose is ranged from $18.00-29.0 \mathrm{mg} / \mathrm{dl}$ with an overall mean of $22.50 \mathrm{mg} / \mathrm{dl}$. The values are presented in the Table -1 .

Table1. Showing blood protein, glucose, cholesterol and triglyceride in four Indian carp fishes Collected from a aquatic body

\begin{tabular}{|l|l|l|l|l|l|}
\hline & Fish Species & Protein $(\mathrm{g} / \mathrm{dl})$ & Glucose $(\mathrm{mg} / \mathrm{dl})$ & Cholesterol $(\mathrm{mg} / \mathrm{dl})$ & Triglycerides $(\mathrm{mg} / \mathrm{dl})$ \\
\hline 1 & Labeo rohita & $3.02 \pm 0.01$ & $21.01 \pm 0.01$ & $202.16 \pm 1.16$ & $336.83 \pm 0.75$ \\
& & $(\mathrm{SE}=0.0057)$ & $(\mathrm{SE}=0.0047)$ & $(\mathrm{SE}=0.4772)$ & $(\mathrm{SE}=0.3072)$ \\
\hline 2 & Catla catla & $3.595 \pm 0.01$ & $18.00 \pm 0.00$ & $272.16 \pm 1.16$ & $285.33 \pm 1.03$ \\
& & $(\mathrm{SE}=0.0042)$ & $(\mathrm{SE}=0.0030)$ & $(\mathrm{SE}=0.4772)$ & $(\mathrm{SE}=0.4216)$ \\
\hline 3 & Cirrhana & $3.10 \pm 0.01$ & $29.01 \pm 0.01$ & $206.5 \pm 1.37$ & $259.00 \pm 1.41$ \\
& mrigala & $(\mathrm{SE}=0.0066)$ & $(\mathrm{SE}=0.0047)$ & $(\mathrm{SE}=0.5627)$ & $(\mathrm{SE}=0.5773$ \\
\hline 4 & Labeo & $2.90 \pm 0.00$ & $22.01 \pm 0.00$ & $211.83 \pm 1.60$ & $300.83 \pm 0.75$ \\
& fimbriatus & $(\mathrm{SE}=0.0040)$ & $(\mathrm{SE}=0.0030)$ & $(\mathrm{SE}=0.6540)$ & $(\mathrm{SE}=0.3072)$ \\
\hline
\end{tabular}

Each value is expressed as mean $\pm S D, N=6$. All values are significant $P=<0.01$

Total Cholesterol (TC) and Triglyceride (TG): Although every living organism examined has been found to contain sterols; cholesterol is found exclusively in animals. Virtually all cells and body fluids contain some cholesterol. Although a portion of body's cholesterol is derived from dietary intake. Cholesterol in the blood of carp fishes is ranged from $202.16-272.16 \mathrm{mg} / \mathrm{dl}$ with an overall mean of $223.16 \mathrm{mg} / \mathrm{dl}$. Thyroid hormones play very important role in the synthesis and degradation of cholesterol and triglycerides. The major lipid fraction is triglyceride, which constitute more than $80 \%$ of the total particles by weight. The enzymes hydrolyze the triglyceride component to mono-glycerol and free fatty acids, which can be taken up at the cellular level for energy metabolism or for resynthesis for storage. The range of triglycerides (TG) in the blood of carp fishes is 285.332 -336.83 $\mathrm{mg} / \mathrm{dl}$ with an overall mean of $295.49 \mathrm{mg} / \mathrm{dl}$. The values are presented in the Table -1 .

\section{DisCUSSION}

Biochemical constituents of fish in the blood are considerable interest for their specificity in relation to food values of fish and evaluating their physiological needs at different period of life.

Serum total protein levels can be used as a diagnostic tool and a valuable test for evaluating the general physiological state in fish (Pedro et al., 2005). Proteins are important for growth and development of the body, maintenance and repairing of worn out tissues and for production of enzymes and hormones required for many body processes. The importance of fish in providing easily digested protein of high biological value is well documented. In the past this has served as a justification for promoting fisheries and aquaculture activities in several countries. Glucose is the primary source of energy for the body's cells and blood lipids (in the form of fats and oils) are primarily a compact energy store. Glucose is transported from the intestines or liver to body cells via, the bloodstream and is made available for cell absorption via, the hormone insulin, produced by the body primarily in the pancreas. The body's homeostatic mechanism keeps blood glucose levels within a narrow range. It is composed of several interacting systems, of which hormone regulation is the most important. There are two types of mutually antagonistic metabolic hormones affecting blood glucose levels catabolic hormones (such as glucagon, growth hormone, cortisol and catecholamine's) which increase blood glucose and one anabolic hormone (insulin), which decreases blood glucose. The importance of blood-borne glucose in the metabolic recovery of some fishes, rainbow trout Oncorhynchus mykiss and winter flounder Pseudopleuronectes americanus (Antonella Pagnotta and Louise Milligan, 1991) has been studied. Cholesterol is a waxy steroid metabolite found in the cell membranes and transported in the blood plasma of all animals. Cholesterol and other components always a miner amounts modify the basic protein /phospholipids pattern of biological membrane in specific ways, with particular functional consequences, estrogen lower plasma cholesterol but increase liver cholesterol with increased cholesterol turnover (Boyd, 1974). Cholesterol is an important component of cell membranes and functions as precursors for the synthesis of sexual hormones, a number of fish species have seasonal variation in cholesterol with increased level during spawning. Total cholesterol is defined as the sum of HDL, LDL. Body makes some triglycerides which come from the food and body uses carbohydrate calories for immediate energy and left over calories are turned into triglycerides and stored in fat cells for later use. 
The health of fish can be affected by environmental factors (stress), nutrition as well as by pathogens. Stress in fish may be induced by various a biotic environmental factors such as changes in water temperature, $\mathrm{pH}$, oxygen concentration and water pollutants including pesticides, insecticides, petroleum products and heavy metals (Witeska, 2005). Biotic interactions such as predator pressure, parasitic invasions or strong competition with other organisms or among the fish in overcrowded areas and by human activities related to fish rearing and harvesting (manipulation, transport) can also be a source of stress to fish (Witeska, 2005). Stress reaction involves various physiological changes including alteration in blood composition and immune mechanisms. The availability of a particular fish species in wild in large numbers reflects that the fish is thriving well in the environment, which is most suitable for its survival, growth and breeding activities. Analysis of the peripheral blood of fish serves for diagnostic purposes; apart from this main purpose. To evaluate the condition of the fish, to evaluate the resistance of fish, to assess the suitability of environmental condition, feeds and feed mixtures, to evaluate the effect of stress situations etc.

In the present study the total protein, blood glucose, total cholesterol and triglycerides levels has been studied in the carp fishes collected from a specific aquatic body. The blood samples were taken between March and April at temperature of $36^{\circ} \mathrm{C}$. The total serum protein was found to be as mean with a range of $2.90-3.59 \mathrm{~g} / \mathrm{dl}$, with an overall mean of $3.15 \mathrm{~g} / \mathrm{dl}$., amongst the four fishes studied. There are some previous reports available on the total serum protein levels range from 2.8 to $8.2 \mathrm{~g} / \mathrm{dl}$. Tavares - Dias et al., 2004). In the fish, A. gigas a tropical fish the total protein plasma level found to be $6.5 \mathrm{~g} / \mathrm{dl}$ (Tavares - Dias et al., 2007) which was slightly higher than those described in T. tinka (Pedro et al., 2005). The higher levels of total protein have been expected as these fishes were carnivores and adult fishes need more protein to form their gonads (Tavares -Dias et al., 2007). In the present study normal ranges of levels in the total serum protein has been found in four fishes, since the fishes were adults and are omnivorous. The total plasma protein studied in clarias garipinus was found to be $4.08 \pm 0.74$ as reported by (Tavares -Dias, 2000). Serum total protein of Acipenser naccarii was $1.9-2.6 \mathrm{gr} / \mathrm{dl}$ according to Cataldi et al., (1998). Asadi et al., (2006) measured total protein values in Huso huso, $(4.51 \pm 1-5.50 \pm 0.94 \mathrm{mg} / \mathrm{dl})$, more or less similar serum proten level has been reported for N.notopterus (Kulkarni and Barad, 2015). The blood glucose estimated in the fresh water fish, N.notopterus under normal condition has been reported by Kulkarni and Barad (2015) was found to be ranged from $40.78-53.78 \mathrm{mg} / \mathrm{dl}$, collected from three aquatic bodies with overall mean of $45.38 \mathrm{mg} / \mathrm{dl}$. Tavares - Dias et al., (2007) reported high glucose level $152.4 \mathrm{mg} / \mathrm{dl}$ for the fish Arapaima gigas and this has been higher than those described for Oncorhynchus mykiss (Rehulka, 2000). The studies on this aspects demonstrated that glucose serum level varied in ecological distinct species, in part influenced by environmental and life mode of the fish, particularly related to its locomotivity (Tavares - Dias and Mataqueiro, 2004; Tavares - Dais, 2004). The higher values occur in active fishes whose feeding habits are in water column or in predators. Lower values are reported for sluggish fish do not migrate due to the reproductive cycle, it is considered as sluggish habit species such a carnivore predator pray and thus displaying moderate serum glucose levels as expected for mobilization of the energetic supplement in response to its habit. In the present study on carp fishes moderate level of blood glucose has been observed and it may be related their feeding. The lipids are the economical usual form used by fishes to stock energy and can be stored in many different organs (Guijarro et al., 2003) The cholesterol and triglycerides plasma levels are found to be with range of $251.40-275.16 \mathrm{mg} / \mathrm{dl}$ and 200.03- 269.61 respectively in the fish N.notopterus (Kulkarni and Barad ,2015 ). In the fish Arapaima gigas reported by Tavares - Dias et al., (2007). The cholesterol range was $150.6-263.7 \mathrm{mg} / \mathrm{dl}$ and triglycerides $154.6-622.7 \mathrm{mg} / \mathrm{dl}$. Thus, the cholesterol and triglycerides plasma levels differ according to age general health conditions and fish feeding diet. In the present study the cholesterol level is lower and triglyceride level is slightly higher as compared to the fish, A. gigas reported by Tavares - Dias et al., (2007). The variation between blood biochemical parameters among fish species depend on various factors, the study on particular species give valuable information on health of economically important fish species. The present study on the fishes may be also helpful in obtaining standard values of blood parameters and examining the correlations between the blood parameters may allow us to understand ecological characteristics of these species.

The results of the present study could be summarized thus: The mean total serum protein was $3.15 \mathrm{~g} /$ $\mathrm{dl}$, mean glucose $22.50 \mathrm{mg} / \mathrm{dl}$, mean total cholesterol is $223.16 \mathrm{mg} / \mathrm{dl}$, mean triglycerides 295.49 $\mathrm{mg} / \mathrm{dl}$, The values obtained for various blood biochemical parameters in the present study for the fresh 
water carp fishes were found to be normal values indicating healthy condition of the fish and the fishes are thriving well in the aquatic body of Gulbarga with favorable environmental conditions.

\section{Conclusions}

The blood electrolyte level has been studied in four species of Indian carp fishes such as Labeo rohita, Cutla cutla, Cirrhana mrigala and Labeo fimbriatus indicates that the values are more or less normal in comparison to other fishes reported. Thus indicating that all the four types of fishes are healthy and are having normal physiological activities for keeping healthy condition and survival in the aquatic body and also probably these four types of fishes are not stressed.

\section{ACKNOWLEDGEMENT}

The author R.S. Kulkarni is grateful to University Grants Commission, New Delhi for selecting Emeritus fellowship (2014-15 batch) No.F-6-6/2014-15/EMERITUS-2014-15-GEN-3514 (SA-II) DT.30-04-2015. We are also thankful to Prof. K. Vijaykumar, Chairman of the department and to Gulbarga University for the facilities to carry out this work.

\section{REFERENCES}

[1] Antonella Pagnotta and Louise Milligan. (1991). The role of blood glucose in the restoration of muscle glycogen during recovery from exhaustive exercise in rainbow trout (Oncorhynchus mykiss) and winter flounder (Pseudopleuronectes americanus). J. exp. Biol. 161: 489-508.

[2] Asadi, F., Halajian, A., Pourkabir, M., Asadian, P. and Jadidizadeh, F. (2006). Serum biochemical parameters of Huso huso. J Comp Clin Pathol., 15: 245-248.

[3] Blaxhall, P.C. and Daisley, K.W. (1973). Routine haematological methods for use with fish blood. J. Fish Biol., 5: 771-781.

[4] Bond, C.E., (1979). Biology of Fishes. Saunders College Publishing, Philadelphia, Pennsylvania.

[5] Boyd, G.S., Brown, M.J.G., Hattersley, N.G. and Suckling, K.E. (1974). Studies on the specificity of the rat liver microsomal cholesterol 0037 $\alpha$-hydroxilase Biochem. Biophys. Acta., 337: 132-135.

[6] Cataldi, E., Di Marco, P., Mandich, A. and Cataudella, S. (1998). Serum parameters of Adriatic sturgeon Acipenser naccarii (Pisces: Acipenseriformes): effects of temperature and stress. $J$ Comp. biochem physiol., 121: 351-354.

[7] Chekrabarthy, P. and Benerjee, V. (1988). Effects of sublethal toxicity of three organophosphorus pesticide on the peripheral haemogram of the fish, (Channa punctatus). Environ. Ecol., 6: 151-158.

[8] Guijarro, A.I., Lopez-Patino, M.A., Pinillos, M.L., Isorna, E., De Pedro, N., Alonso-Gomez, A.L., Alonso-Bedate, M. and Delgado, M.J. (2003). Seasonal changes in haematology and metabolic resources in the tench. J. Fish Biol., 62: 803-815.

[9] Kulkarni R. and Barad V. (2015). Blood chemistry of the fresh water fish, Notopterus notopterus collected from thre different aquatic bodies. Int.J. Biol. \& Pharm.Scs. 2 (3) pp.13-19.

[10] Mawdesley-Thomas, L.E. (1971). Toxic chemicals, the risk to fish. New Scientist 49: 74-75.

[11] Mungikar, A.M. (2003). Biostatical analysis, Saraswati Publ. Aurangabad.

[12] Pedro, N., Guijarra, A. I., Lopez-Patino, M.A., Martinez-Alvarez, R. and Delgado, M.J. (2005). Daily and seasonal variations in haematological and blood.

[13] Rehulka, J. (2000). Influence of astaxanthin on growth rate, condition and some blood indices of rainbow trout, Oncorhynchus mykiss. Aquaculture, 190: 27-47.

[14] Roberts, R.J., (1981). Patologia De los peces. Madrid, Mundi - Prensa, pp: 336.

[15] Tavares-Dias, M and Mataqueiro, M.I. (2004). Caracteristicas hematologicas, bioquimicas e biometricas de piaractusmes opotamicus Holmberg, 1887 (Osteichthyes: Characidae) oriundos de cultivo intensive. Acta Scientiarum., 26: 157-162.

[16] Tavares-Dias, M. (2000). Haematological characteristics of hybrid Florida red tilapia (Orechromis niloticus x O. mossambicus under intensive rearing. Proceeding from the fifth International Symposium on Tilapia aquaculture., 2: 533-541.

[17] Tavares-Dias, M. and Moraes, F. R. (2007) Leukocyte and thrombocyte reference values for channel catfish (Ictalurus punctatus Raf.), with an assessment of morphological, cytochemical and ultrastructural features; Veterinary Clinical pathology., 36, 49-54.

[18] Witeska, M. (2005). Stress in fish - Hematological and immunological effects of heavy metals. Electronic J. Ichthyology., 1:35-41. 


\section{AUTHOR's BIOGRAPHY}

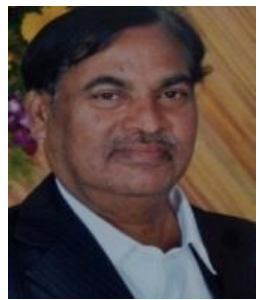

Dr. Raghavendra S. Kulkarni, did his M.Sc. in Zoology from Karnatak University, Dharwad and Ph.D. in Zoology from Banaras Hindu University, Varanasi. He has teaching and research experience of 33 years. He is presently working as UGC Emeritus Professor of Zoology (2015-17) at the Department of studies in Zoology, Gulbarga University, Gulbarga-585106, INDIA. He has published more than 130 research publications in reputed journals and successfully guided 12 students for Ph.D. degree and 20 students for M.Phil degree. He has visited Japan, Belgium, Germany, France, Singapore Nepal and Ethiopia for attending International conferences and academic activities. He is recipient of Eminent Scientist and Best Scientist award from National Environmental Science Academy, New Delhi during 2007 along with fellowships with title from Zoological Society of India (FZSI), bAcademy of Environmental Biology (FAEB) and society for science and Environment (FSSE) 